\title{
THE
}

\section{Continuing education for public library staff: Valued competencies and preferred delivery format}

\author{
Mary Moen \\ University of Rhode Island, mary_moen@uri.edu \\ Lauren H. Mandel \\ University of Rhode Island, lauren_mandel@uri.edu \\ Valerie Karno \\ University of Rhode Island, vkarno@uri.edu
}

Follow this and additional works at: https://digitalcommons.uri.edu/lsc_facpubs

The University of Rhode Island Faculty have made this article openly available.

Please let us know how Open Access to this research benefits you.

This is a pre-publication author manuscript of the final, published article.

Terms of Use

This article is made available under the terms and conditions applicable towards Open Access Policy Articles, as set forth in our Terms of Use.

\section{Citation/Publisher Attribution}

Moen, Mary H., Mandel, Lauren H., and Karno, Valerie. 'Continuing Education for Public Library Staff: Valued Competencies and Preferred Delivery Format'. 1 Jan. 2020: 177-198.

Available at: http://dx.doi.org/10.3233/EFI-190311

This Article is brought to you for free and open access by the Graduate School of Library and Information Studies at DigitalCommons@URI. It has been accepted for inclusion in Graduate School of Library and Information Studies Faculty Publications by an authorized administrator of DigitalCommons@URI. For more information, please contact digitalcommons-group@uri.edu. 
Continuing education for public library staff:

Valued competencies and preferred delivery format

\section{Abstract}

As the nature of public library services expands and transforms, continuing education (CE) for both degreed and non-degreed library staff is critical. An ongoing challenge for the LIS community is to identify the key areas in which to increase professional knowledge and skills. The purpose of this study was to identify what working library staff considered valued competencies for youth services, reference services, director, and non-degreed library staff positions, as well as their preferred delivery format for CE. Open-ended survey activities were conducted via four research sessions, with a total of 57 library staff members participating in the study. The findings from the study suggest that the preferred CE delivery format is low-cost or no-cost, limited-time-commitment workshops with high interactivity. Valued competencies identified in the study indicated interdisciplinary trends of business management skills for library directors; technology skills and diversity/inclusion training for library staff and adult services/reference librarians; and knowledge around child and adolescent cognitive, behavioral, and literacy development for youth librarians. The findings from this study will help inform LIS schools and other CE providers on how best to create and deliver CE that meets the needs of public library staff.

Keywords: continuing education, professional development, LIS schools, LIS competencies, LIS education 


\section{Introduction}

Amidst this transformative era for libraries, an ongoing challenge for the LIS profession is to identify key areas to increase professional knowledge and skills (Harhai \& Krueger, 2016; OCLC/IMLS, 2013). Propelled by changing demographics and broadened community interests, public libraries have expanded services to include: innovation labs, which are places for the community to create content and engage in DIY projects; science, technology, engineering, and math (STEM) programming and collection development; early learning and early literacy programming and materials (Thompson, 2015); and the creation and provision of safe spaces for learning, socializing and leisure activities (Bolan, 2016).

In addition to identifying the knowledge and skills for public library staff to stay relevant, it is important to discern the most effective mechanisms for delivering CE to professional library staff. The Internet has expanded access to CE and offers a range of learning platforms and methods. Learners can now choose from a multitude of options based on their schedule, budget, learning style, and level of commitment. As a result, a second challenge for CE developers, including LIS schools, is to determine the best ways to deliver professional learning to library staff (Harhai \& Krueger, 2016).

After implementing a successful CE program developed to advance the digital and media literacy skills of practicing youth librarians funded by an Institute of Museum and Library Services National Leadership Grant, the research team at U.S. university was inspired to explore what other knowledge and skills were in demand in the LIS field. They chose to focus on what practicing public library staff perceived as important CE topics for four types of positions: director, adult services/reference librarian, children's and young adult (YA) librarian, and non- 
degreed library staff, as well as their preferred delivery format for CE. The results from the study could inform the development of CE opportunities as well as curricular improvements for current students at this university's LIS program.

\section{Literature Review}

\subsection{Competencies of LIS professionals}

Over the past two decades, a substantial effort in competency development and revision of existing competencies has been conducted by the American Library Association (ALA) and its divisions, library associations of Australia (ALIA, 2014) and the U.K. (CILIP, n.d.), state library organizations in the U.S., and scholars around the world. These efforts have been spurred by the need for library staff to keep up with trends, particularly those due to the disruptive technologies that have impacted library services, resources, and user needs (Harrison, 2010). Nonthacumjane (2012) argues in his literature review of international research studies that the digital era has required a new set of skills and competencies for the next generation of LIS professionals. One of the main reasons that researchers and organizations are interested in defining the competencies needed to be a librarian today is not only to inform curriculum at LIS programs but also to develop CE opportunities that support attainment of current knowledge areas and skill sets (Ohio Library Council, 2014; Rafiq, Jabeen, \& Arif, 2017; State Library of North Carolina, 2015).

The library competencies developed by the ALA (2008), ALIA (2014), and CILIP (n.d.) are used by LIS schools and others to provide standards for students in library programs, as well as for practicing members of the profession to guide their professional development efforts. Although ALIA and CILIP's competencies are for LIS professionals as a whole, the ALA divisions 
have developed field specific competencies. Looking across all seven of the division competencies that have been developed (ALA, 2008), four have been identified as relevant to this investigation of public library staff. These are: a) Library Leadership and Management Association (LLAMA), b) Association for Library Service to Children (ALSC), c) Young Adult Library Services Association (YALSA), and d) Reference and User Services Association (RUSA).

LIS competencies that are applicable to public library contexts have also been created in at least three states, North Carolina (2015), Ohio (2014), and Arizona (n.d.). North Carolina focuses solely on technology competencies for any library staff person. Ohio identifies core competencies for 15 different library positions in a large public library system. Arizona created library practitioner competencies for non-MLS staff interested in meeting state certification requirements. Looking across these three state initiatives and the ALA (2008), ALSC (2015), LLAMA (2016), RUSA (2017), and YALSA (2017) competencies, common topics emerge:

- collection management (ALA, 2008; ALSC, 2015; Arizona, n.d.; North Carolina, 2015),

- information literacy (ALA, 2008; ALSC, 2015; North Carolina, 2015; RUSA, 2017),

- $\quad$ outreach, marketing, and advocacy (ALSC, 2015; LLAMA, 2016; Ohio, 2014; RUSA, 2017; YALSA, 2017),

- reference services (ALA, 2008; ALSC, 2015; RUSA, 2017),

- $\quad$ user engagement (ALSC, 2015; Ohio, 2014; RUSA, 2017; YALSA, 2017), and

- technology skills (ALA, 2008; Arizona, n.d.; North Carolina, 2015; Ohio, 2014).

Although technology skills are often considered paramount for library staff, only the ALA (2008), Ohio (2014), North Carolina (2015) and Arizona (n.d.) competency documents specifically list technology skills as a separate category title of competencies. 
Technology competencies, moreover, have received attention from researchers around the world. Findings indicate that the technology and computer skills necessary for LIS leaders in Pakistan include advanced technical tools such as database management, digital library design and maintenance of digital libraries (Hamid \& Soroya, 2015), as well as computer applications in LIS, computer applications in research, digital library, digital preservation, and library automation (Rafiq et al., 2017). A study in the U.S. found that important competencies include knowledge and skills in training patrons how to use digital resources and productivity tools (Heinrichs \& Lim, 2009). Conceptual models of information and computer technology (ICT) skills were developed for LIS professionals in India that indicated skills in three levels of ICT competency: basic, capable, and expert (Tyagi, Yanthan, Kumar, \& Tyagi , 2018). This level of detail matches the Ohio (2014) and North Carolina (2015) competencies, and is supported by the ALA core competencies (2008), but it contrasts with the lack of focus on specific technology skills in the ALA Division competencies (ALSC, 2015; LLAMA, 2016; RUSA, 2017; YALSA, 2017). Marketing, research skills, and management skills have also been identified as top priorities. Hamid and Soroya (2015) indicate that knowing how to market library products and services is an important competency for librarians. The focus on outreach, marketing, and advocacy skills in the LLAMA (2016), ALSC (2015), RUSA (2017), Ohio (2014), and YALSA (2017) competencies supports their research. Hamid and Soroya (2015) also found that skills in research methods such as citation management, referencing and bibliography, online database searching skills and advanced search strategies were important. Research skills are mentioned in the ALA core competencies (2008) and throughout the RUSA (2017) competencies. 
The demand for both hard and soft management skills is apparent in the research. For example, LIS professionals in Pakistan felt they lacked basic hard management skills (Khan \& Rafiq, 2013) yet for LIS leaders in Kuwait, soft skills such as commitment to high ethical and professional standards, self-confidence, trustworthiness, and initiative were prioritized over hard skills (al Ansari \& al Khadher, 2011). In Israel, hard skills such as providing information services were rated more important than personal skills (Bronstein, 2015). Both hard management skills such as project management, marketing, and budgeting and soft skills such as emotional intelligence, forward thinking, and communication are the focus of the LLAMA competencies (2016); these also appear in the ALA (2008), ALSC (2015), and Ohio (2014) competencies.

Soft skills have also been identified by librarians as being even more critical for public librarianship than the need to advance technology skills (Bronstein, 2015; Partridge, Lee, \& Munro, 2010). Examples of attributes listed in the competency documents include: respect for diversity (ALSC, 2015; YALSA, 2017), adaptability (Ohio, 2014), willing to learn from mistakes (LLAMA, 2016), communications - both verbal and non-verbal (ALA, 2008; LLAMA, 2016; Ohio, 2014; Partridge et al., 2010; RUSA, 2017; Saunders \& Jordan, 2013; YALSA, 2017), motivation to continue professional learning (ALA, 2008; ALIA, 2018; ALSC, 2015; Arizona, n.d.; YALSA, 2017), social skills/customer service (ALIA, 2018; LLAMA, 2016; Ohio, 2014; Saunders \& Jordan, 2013; YALSA, 2017), and relationship builder (ALA, 2008; ALIA, 2018; ALSC, 2015; Arizona, n.d.; IFLA Library Services to Children and Young Adults Section \& Rankin, 2018; LLAMA, 2016; RUSA, 2017; YALSA, 2017). 
Organizations that concentrate on children's library services have identified desirable personal traits specific to the needs of their particular user groups. Being comfortable interacting with children and teens (ALSC, 2015; YALSA, 2017), developing cultural awareness (ALSC, 2015; YALSA, 2017), cultivating a welcoming environment (IFLA Library Services to Children and Young Adults Section \& Rankin, 2018), and having the ability to self-evaluate professional strengths and weaknesses (IFLA Library Services to Children and Young Adults Section \& Rankin, 2018) are some examples. The findings from a study of children's librarians in Taiwan (Peng, 2019) helped develop a competency model for public children's librarians that was in strong alignment to the ALSC competencies (2015), but also identified new categories for personal traits such as vivacious, patient, and loving.

Clearly, the competencies identified as important for public library staff are numerous. Each position has its own special focus and needs. Furthermore, public libraries are continuing to take on broader roles specific to their communities. These responsibilities may require additional competencies not identified by existing competency frameworks. Current public library services available at public libraries include, but are not limited to, social services for the homeless and addiction (ALA, 2019), racial justice (ALA, 2019), restorative justice (MacPherson, 2019), opioid crisis response (ALA, 2018), health literacy and information (ALA, 2019; Popoola, 2019), census taking (ALA, 2019), early literacy strategies for caregivers (Jordebrek, 2019), digital literacy (ALA, 2018), computer coding (Christou, 2019), yoga and mindfulness (Johns, 2019), mental wellness (Peet, 2019), storytimes for autistic children (Damron, 2019), book clubs for adults with disabilities (Marcotte, 2019), and makerspaces (Abron, 2019). These are services already being provided in libraries and this list could expand to include trends identified by the 
Library of the Future (2014) initiative that include programs in drones, blockchain, virtual reality, gamification, virtual reality, and other STEM topics.

\subsection{Preference of CE Delivery Formats}

Library staff have more opportunities for CE than ever before thanks to the Internet.

Webinars, online university courses, Twitter edchats, professional social networks, and Massive Open Online Courses (MOOCs) are some of the online delivery formats available for professional learning. A small body of research has studied the preferred delivery formats in online environments. Learners in online university LIS courses perceived that the accommodation of their schedule, a broader selection of course offerings, and consistency in delivery were benefits, while isolation from peers and instructors was a drawback (Oguz, Chu, \& Chow, 2013). Students in hybrid courses where some instruction was delivered online and some face-to-face, indicated that these types of courses were less robotic and provided a diversity of instructors and learning experiences, yet oftentimes confusing (Oguz et al., 2015). Stephens (2013) piloted a MOOC for LIS CE that encouraged LIS professionals to play the role of learner, connecter, and collaborator in an online environment. Although the study did not include participant evaluation of the MOOC experience, plans for future research included looking at ways to make MOOCs more appealing to LIS professionals.

Communities of practice are one way to overcome the isolation barrier and connect learners by building social learning experiences in an online LIS course (Burns, Howard, \& Kimmel, 2016; Marken \& Dickinson, 2013). These spaces are often outside the traditional class structure and can include emails, social media platforms, text messaging, and even face-to-face meetings. Students in a school library education program who engaged in community of 
practice activities reported a growth in their understanding of community in an online class and for their profession as a whole, while still acknowledging time and technical difficulties as challenges (Burns et al., 2016).

Considering face-to-face CE delivery modes, Vega and Connell (2007) conducted a survey of library professionals about their attitudes towards conferences as a means of professional development. Professional rejuvenation and networking were the top reasons cited for this format. Cost and travel were common disadvantages of conference attendance. Harrison's (2010) literature review indicated that conference attendance provided "the unique benefit of allowing one to learn about many or all current trends in a relatively brief amount of time" (p. 265). In addition, she argues that conferences give participants the chance to have questions answered by experts and engage in conversation with peers on the topic, opportunities for hands-on learning, and demonstrations of new projects and resources.

The usefulness of CE program types was explored by Rafiq et al. (2017). Their survey findings indicated that the most useful program types were credit hour course, post-master's certificate, postgraduate diploma, and workshop. A focus group of librarians reported that hands-on learning for technology was highly valued. Preferences for time of day to offer CE indicated late afternoon, evenings, or weekends so as not to interfere with work. Several barriers to CE were described, such as cost, time commitment, location, lack of motivation, and lack of recognition for attending.

With the plethora of delivery options available and the wide range of benefits and barriers, CE providers have their work cut out for them to design effective CE. A recommended step is to conduct a needs assessment of their target audience (OCLC/IMLS, 2013; Rafiq et al., 
2017). This study explores the perceived CE needs of library staff who work in a specific geographic region and hopes the findings will inform CE developers, including LIS schools.

\section{Methodology}

The methods used in this study were survey and focus group activities. Survey research is the most commonly used method in LIS research since 1980 (Ullah \& Ameen, 2018), and a useful method for exploratory research to measure outlooks and preferences (Babbie, 2015). Focus group interviews are an effective way to elicit qualitative responses from a small group of participants using open or close ended questions.

The participants were asked five core questions: 1) What knowledge and skills do children's/youth librarians need? 2) What knowledge and skills do adult services/reference librarians need? 3) What knowledge and skills do library directors need? 4) What knowledge and skills do library staff (para-professionals) need? 5) What is your preferred delivery format for CE and why? Data was collected during one-hour sessions in which participants answered the five questions by engaging in three hands-on activities: a gallery walk to record and vote on responses to open-ended questions; a think/pair/share task to complete a written questionnaire worksheet; and a consensogram (a consensus seeking technique) to quantitatively indicate preferences from the worksheet.

Exploration of new types of methodology in LIS research gained momentum after 1990 and are helpful to identify strengths and gaps in the use of methodologies in LIS research (Ullah \& Ameen, 2018). Based on the results of using these less common data collection strategies during a conference workshop, the researchers were inspired to explore untraditional approaches to LIS research methods. They designed the study to collect qualitative and 
quantitative data through activities that involved social interaction and engagement of participants, rather than more traditional means reliant on closed-ended questions (such as a survey instrument) or the formality of a researcher-led focus group. The intent of using the more informal, hands-on data collection processes was to fully engage participants in the process and elicit responses from all. Unexpected benefit the researchers observed during the data collection process were collegial networking, sharing of issues and concerns, and learning from others.

\subsection{Sample}

The convenience sample method was used to recruit a total of 57 participants who had attended CE events held during a two-month time period. Three events were workshops on stop motion animation that were organized and facilitated by the researchers. The workshops were held at the state library CE facilities in State 1, State 2, and State 3. The first half of the session lasted one hour and focused on teaching the participants how to facilitate a stop motion animation workshop in their library. In the second hour, participants volunteered to stay for the research study. A fourth session was held during the mid-day break at a regional library association's annual conference when attendees volunteered to participate in the research session. Of the 57 total participants, 15 were from the CE session in State 1, 10 from State 2, 10 from State 3, and 22 from the regional conference. All participants signed informed consent forms prior to participating; demographic data on the participants was not collected. Use of a convenience sample of library staff who attended face-to-face CE events in one region of the country is a limitation to the generalizability of this study.

\section{Data Collection}




\subsection{Gallery Walk}

In a gallery walk activity, participants are asked to respond to a set of open-ended questions during a specified time frame (in this case, questions 1-4 listed above). Gallery walks by definition are a means to actively engage participants by having them walk around sharing ideas and responding to questions at stations throughout the room (McCafferty \& Beaudry, 2017). For this study, researchers used the gallery walk to collect participants' perceptions of the necessary knowledge and skills for four different types of library staff positions: a) library director, b) adult services/reference librarian, c) children's/YA librarian, and d) library staff. There was one station for each library staff type, identified by a large poster on the wall. The researchers wrote on each poster the library position and the open-ended survey question "What knowledge and skills do I need?" Participants were split into four groups and assigned a station to start. There were 2-4 participants in each group, depending on the total number of participants at the session to ensure four groups at each gallery walk session. The researchers gave each participant approximately $253^{\prime \prime} \times 3$ " post-it notes and a pen, but they could ask for more if they needed them. Participants were instructed to take two minutes to individually write down one idea per post-it note of what they thought were necessary knowledge and skills for that position. The two-minute time interval was determined by the constraints of a onehour session. Participants could individually post an idea, but if they agreed with someone else's idea, they were instructed to put a star on the other person's post-it to indicate a vote of support, rather than duplicate the idea on a new post-it. Participants were allowed to talk with the people in their small groups as they cycled around the gallery walk. After a two-minute interval, groups were instructed to rotate to the next station and the process was repeated 
until they had circled back to their original station. At this point, participants were given two additional minutes to review what others had posted at their original station and arrange them by common theme. Participants took turns reporting out the common themes of each job position. The researchers adhered the post-its on each poster with tape immediately at the conclusion of the focus group to ensure the integrity of the data. See Table 1 for totals of postits and votes per library position that were collected and Figure 1 for a photo of one of the completed stations.

Advantages of the gallery walk were similar to traditional focus groups. The participants could see each other's responses and make additional comments beyond their own. The social interactions among the participants created an enjoyable and non-threatening environment to respond to the questions. Furthermore, shared or contrasting views could be relatively and quickly assessed (Patton, 2002). An additional benefit to the gallery walk was that people who may have been reluctant to speak in a focus group were able to engage in the discussion by writing their ideas down. This method also reduced the chance of a participant dominating the conversation. Limitations of this method were the constraints of the post-it note process. Although the $3 "$ × 3 " size encouraged participants to summarize their ideas, it may have prohibited participants from providing a deeper level of detail. In addition, following directions was a minor issue. Participants were instructed to put one idea on each post-it but a few postits had more than one idea written on them which was addressed in the data analysis. Another limitation to the gallery walk activity could be peer bias. Peer bias was reduced because each participant was given their own pen and their own post-it notes, and instructed to write down their ideas, or individually check off ideas they agreed with, not to work as a group. The 
researchers also tried to reduce peer bias by only having small groups of 2-4 participants at each station at one time so their input was not easily visible or noticed by the other groups.

\subsection{Think/pair/share questionnaire}

The second activity consisted of a think/pair/share collaborative task in which participants worked in teams to discuss and complete a questionnaire responding to the question "what is your preferred delivery format for CE and why." Participants identified the pros and cons of eight learning formats on the questionnaire: a) one shot workshop, b) series of workshops over several weeks, c) face-to-face, d) combination of face-to-face and virtual sessions, e) webinar, f) face-to-face university 1-3 credit course, g) online university 1-3 credit course, and h) postgraduate 12-credit certificate. Participants could also add their own idea for a delivery format. Participants had 10 minutes to talk amongst their group and complete the questionnaire. Advantages of the think/pair/share activity are that it encourages confidence and participation in discussion (Hamden, 2017; Sampsel, 2013). Using this method in research provided the participants the opportunity to collaboratively build knowledge together to create robust lists of pros and cons. When the time was up, participants were asked to take what they learned in this activity and transition to the third activity, a consensogram. A limitation to the think/pair/share task was that not every questionnaire was filled out completely due to time constraints.

\subsection{Consensogram}

The consensogram is a consensus gathering technique that was used to gather additional detail in response to the question "what is your preferred delivery format for CE and why." The idea behind the consensogram is that participants are developing a consensus 
opinion together, meaning that their opinions have to be shared publicly with one another to reach consensus. Consensus gathering techniques have been used in LIS research (Ullah \& Ameen, 2018). Although their use is infrequent, this study may help increase awareness of the possibilities of the technique. The researchers used one graphic organizer for each session drawn by the researchers on a large post-it poster that included a column for each of the eight learning formats and a place for "other" at the bottom. Each participant was given six stickers and instructed to identify their preferred learning format by placing the stickers in the appropriate column. Participants were told to use all of their six stickers to ensure each participant voted the same number of times, and they had the option to place as many stickers as they wanted in any category, including "other," such that they could give six votes to one category or split their votes across up to six categories. See Figure 2 for an example of one of the completed consensograms.

An advantage of the consensogram activity is that participants had the opportunity to not only identify their preferences for CE formats in the think/pair/share questionnaire but could then weigh their responses using the stickers. Peer pressure is a possible limitation of the consensogram activity since participants were placing their votes on one large consensogram and could have been influenced by how others had placed their votes before them. To reduce peer pressure, the participants had time in the think/pair/share activity to discuss their own opinions and think about pros and cons before they were explicitly instructed by the researchers to place the stickers on their personal preferences on the consensogram.

5. Data Analysis 
Gallery walk data was analyzed using the inductive content data analysis technique in a two-step process. In the first step, the words or phrases and corresponding number of stars (votes) on each post-it were entered on an Excel spreadsheet. Then the items were grouped by common theme into broad categories per library position. This data analysis strategy is a way to develop a more uniform list of responses to an open-ended question (Babbie, 2015). The categories were determined by inductive approach by the first coder. Percent agreement was used to calculate the reliability of the coding scheme. A second coder was given $10 \%$ of the data items, all the category titles, and the codebook with a result of $91.9 \%$ overall agreement reached.

At this point, the researchers decided that subcategories would more precisely identify the knowledge and skills needed for each library position. Therefore, the second step of the data analysis procedure was to conduct a content analysis of the items in each of the broad categories to determine more detailed sub-categories for each library position. The first coder determined the sub-categories inductively and applied them to the entire dataset before giving the second coder $10 \%$ of the data items, all the sub-category titles, and the codebook. Percent agreement was again used to calculate the reliability of the coding scheme with a result of 92.1\% overall agreement reached.

The data from the think/pair/share worksheet on preferred learning formats was aggregated onto a master learning formats Excel worksheet. The pros and cons statements for each learning format were aggregated and quantified by frequency. Similar terms were combined such as "cost" and "\$," or "travel" and "travel time." The number of stickers in each learning format category from the consensogram were tabulated and recorded. 


\section{Findings}

\subsection{Valued competencies by job title}

Tables 2-5 show the competencies identified by participants for library directors, adult services/reference librarian, children's/YA librarian, and library staff during the gallery walk. Competencies for library director received more total votes $(n=283)$ than for any of the other three positions ( $n=235$ for library staff, $n=258$ for children's/YA librarian, and $n=250$ for adult services/reference librarian). Overall, competencies for all four types of positions received between 235 and 283 votes, indicating participants gave similar consideration to the competencies needed for all four types of library position. The average number of votes per job title was 256.5. The researchers determined that participants were indicating that "priority" competencies were those that received 25 or more votes (i.e., $10 \%$ of the average number of votes per job title).

For library director (Table 2), the most commonly identified category of competencies was library management $(n=121)$, which is fairly logical given that managing the library is the director's primary responsibility. Priority competencies for library director were library operations $(n=45)$, financial know-how $(n=31)$, strategic planning $(n=25)$, general communication skills $(n=45)$, and community engagement $(n=32)$. Only two sub-categories of competencies were identified as priority for library staff (Table 3): library resources, systems, and service $(n=38)$ and customer experience $(n=52)$. It might be that because library staff perform diverse tasks in varied roles, there was less agreement among participants about the critical competencies for library staff. For librarians working with youth, participants identified four sub-categories of competencies as priority (Table 4): creative and flexible $(n=37)$, socio- 
emotional understanding $(n=25)$, children/teen development $(n=35)$, and literacy development and support $(n=36)$. For adult services/reference librarians, participants identified five subcategories of competencies as priority (Table 5): people skills $(n=31)$, customer experience $(n=31)$, knowledge of and competency with library resources and services $(n=27)$, readers advisory ( $n=25)$, and computer/technology knowledge and skills ( $n=41)$.

In looking across all four library positions, library management $(n=121)$ was the most commonly identified category of competencies. Interpersonal skills and personal traits emerged as categories of competencies for all four positions (Tables 2-5). Technology competencies emerged as a category of competencies for library staff (Table 3) and adult services/reference librarian (Table 5), but were not identified for library director (Table 2) or children's/YA librarian (Table 4). This is of note since the literature gives heavy emphasis to technology skills and competencies training for all types of librarians and library staff (Hamid \& Soroya, 2015; Heinrichs \& Lim, 2009; Rafiq et al., 2017). It is also a common focus of state and regional trainings for librarians and library staff (ALA, 2008; North Carolina, 2015; Ohio, 2014). None of the three sub-categories identified as critical for children's/YA librarian (creative and flexible, children/teen development, and literacy development and support; see Table 4) were identified as competencies for any of the other three library positions considered by participants during the gallery walk.

From the data, a picture is beginning to emerge of how librarians and library staff view the varied roles of library director, library staff, children's/YA librarian, and adult services/reference librarian. A library director should be competent at traditional management skills; library staff and adult services/reference librarians need strong technology and customer 
service skills; and children's/YA librarians need specific knowledge related to youth development and literacy. All four types of positions are perceived to need interpersonal skills and specific personal traits. A summary of the perceived important competencies for each library role are in Table 6.

\subsection{Preferred delivery of professional learning}

The one shot workshop was the most preferred delivery format with 65 votes, followed by series of workshops ( $n=52)$, combination face-to-face/online $(n=41)$, webinar $(n=39)$, and face-to-face $(n=39)$; see Figure 3. The least popular choices were internship $(n=3)$, face-to-face university course $(n=5)$, and certification program $(n=9)$. This contrasts with Rafiq et al.'s (2017) findings that preferred formats were credit hour course, post master's certificate, postgraduate diploma, and workshop. Given that the participants in this study were library staff who chose to attend a face-to-face one shot workshop, their preference for that format over more time intensive formats might be skewed by the convenience sample used in this study.

Participants identified pros and cons for all training formats listed on the think/pair/share worksheet (Table 7). The training formats with the most pros identified were series of workshops $(n=29)$, one shot workshop $(n=28)$, online university course $(n=26)$, and webinar $(n=24)$. Only one shot workshop, series of workshops, face-to-face, and combination face-to-face/virtual had more pros than cons. All other formats received more cons than pros. Even workshop formats with many pros like online university course and webinar might still be outweighed by their cons when library staff are considering their CE options.

Participants listed 59 different pros and 46 different cons. The most commonly cited pros are 
- in depth $(n=20)$, reported for post-graduate 12 -credit certificate, combination face-toface and virtual sessions, series of workshops, and face-to-face university course,

- convenience $(n=17)$, reported for online university courses and webinars,

- networking opportunities/chance to meet people/colleagues $(n=11)$, reported for one shot workshop, series of workshops, face-to-face, and combination face-to-face and virtual sessions, and

- interactive $(n=10)$, reported for combination face-to-face and virtual sessions, one shot workshop, face-to-face university course, and series of workshops.

Two other pros could also be considered "interactive": ability to ask questions, discuss and exchange ideas $(n=6)$ in face-to-face, and hands on $(n=8)$ in one shot workshop, face-to-face, and face-to-face university course.

The most commonly cited cons were related to time and cost issues:

- $\quad$ cost $(n=37)$, reported for face-to-face university course, online university course, and postgraduate 12 -credit certificate,

- time constraints ( $n=32)$, reported for face-to-face, face-to-face university course, series of workshops, postgraduate 12 -credit certificate, online university course, and combination face-to-face and virtual sessions,

- travel $(n=26)$, reported for series of workshops, combination face-to-face and virtual sessions, face-to-face university course, post-graduate 12 -credit certificate, face-to-face, one shot workshop, and face-to-face), and

- $\quad$ schedule conflicts $(n=14)$, reported for one shot workshop, face-to-face, and series of workshops. 
These 109 cons comprise $56.5 \%$ of all cons and align with Rafiq et al.'s findings regarding barriers to CE (2017). It may be worth asking how the purveyors of professional development can make those opportunities worth librarians' time.

The only format that did not have anyone report a time-related con was webinar. Yet webinar had more cons than pros. The top two cons for webinar were technical issues and less or no interaction ( $\mathrm{n}=5$ for both). Further research may be necessary to determine whether the myriad perceived cons of webinar outweigh its one major pro, being more convenient ( $n=12)$.

\section{Discussion}

\subsection{Valued competencies for CE}

The findings indicate that oftentimes knowledge and skills from disciplines outside the traditional LIS curriculum are needed. In addition to library operations, library directors are expected to have broader knowledge in a range of areas, including: business management knowledge, such as financial expertise in fiscal budgeting, data analysis, and data visualization; project management skills, including strategic planning and outcomes assessment; human resource competencies that address mentoring, change management, motivating, and training; and communication skills around listening, providing effective feedback, being politically savvy, and interacting with diverse patrons. Having the skills to reach out and engage with the community is also desired. One can conclude that business management and leadership skills are a necessary part of learning for library professionals seeking to be directors, for those who are current directors, and even for LIS students to better prepare them for success.

Adult services/reference librarians should be also be effective communicators, with a desired focus on customer experience, especially when working with diverse patrons. 
Developing cultural intelligence to equitably serve the needs of all patrons and increasing knowledge about mental health are important for improving professional expertise in diversity and inclusion education, in addition to gaining knowledge about the social services fields. Adult services/reference librarians are also expected to have high knowledge of and skills with technology including expertise in technology devices, applications, and troubleshooting problems, areas that could cross into the larger fields of data and computer science. These fields of expertise may be beyond what is currently taught at many LIS schools.

Children's/YA librarians should be creative and flexible, traits that can be developed through activities such as improvisation and design thinking projects, which bring the performing arts and engineering fields into play. Children's/YA librarians should have knowledge of child and adolescent cognitive and behavior development, as well as literacy development, both cross disciplinary areas that address new expertise domains necessary to be a successful librarian working with youth.

The expectations for what library staff without LIS degrees should know and be able to do are broad and high. Library staff should be skilled in library operations across departments and have well-developed customer experience skills. These are basic LIS skills. One solution to support library staff in developing foundational LIS competencies would be to encourage them to obtain additional education. Creating systems to offer and recognize learning such as certificates or badges could be explored in lieu of formal degrees. Supporting library staff success is an issue that needs further attention.

\subsection{Preferred delivery formats for CE}


The delivery format most preferred by participants in this study are low- or no-cost, limited-time-commitment workshops with high interactivity. Although webinars are a potential means to deliver low-cost one-shot workshops, the lack of interactivity of that format was a concern. Online learning overall was reported as less desirable due to potential distractions and lack of motivation. Strategies for how to deliver online learning better and how to support CE learners in getting the most out of online learning are areas of possible future research. Although the disadvantages of online learning were greater than the advantages in this study, online education makes learning more accessible and convenient to all. This fact alone makes it worthwhile to explore the criteria for quality online learning experiences that are effective for librarians and library staff.

Another factor to consider is that the librarians in this study indicated they believe online learning is not interactive and therefore not as "good" as face-to-face learning. It is possible that these librarians have only been exposed to webinars that follow a more traditional lecture-style format or are self-paced modules that rely heavily on reading or videos and do not include interactivity that can be achieved through discussion boards, live streaming sessions through tools like WebEx and Collaborate, and team-based projects.

Learning online also requires a commitment to self-directed learning, which may further contribute to the view of online learning as being less desirable than a single face-to-face workshop where the participants are physically present and incentivized to participate. In the online environment, one can easily enroll in a course and get distracted by other commitments or lack the motivation for self-directed learning, and end up not having participated sufficiently to achieve the learning objectives. 


\section{Conclusion}

This study is significant because it provides current data from "boots on the ground" library staff on what they believe are important competencies for different library positions, and their preferences for the delivery format of CE. Library staff are the people who engage with library users daily and know what is missing from their knowledge base that would most help them in moving libraries forward into the future. Hence, it is important to collect and attend to information gathered from library staff to assist them in ensuring that library patrons have access to the most effective library services possible. From this research, it is clear that library staff see a need for CE to keep current with changing trends, including the need to seek training and education outside of content areas traditional to library education. Areas for CE include a wide range of topics: leadership, business, and communication skills for library directors; technology and skills to communicate and serve diverse patrons for adult services/reference librarians; learned traits of creativity and flexibility as well as knowledge of literacy, child, and adolescent development for youth services librarians; and more advanced library operations and customer experience skills for library staff.

While data from library staff is essential, a recommendation for future research would be to survey library users about their expectations for library staff. A comparison between what library staff think they should know and be able to do and what patrons think is important for library staff to know and be able to do would be informative to library staff, competency writers, and CE developers. In addition, further research to thematically group the CE topics may help operationalize the findings of this study. 
There are numerous options for the delivery format of CE. This study reported what library staff consider as pros and cons of different online and face-to-face formats as well as more formal vs informal learning opportunities. The findings indicate providers of LIS CE should focus on cost effectiveness, convenience, and worthwhileness of CE opportunities for library staff. Future research could explore the impact different formats have on learning achievement and level of satisfaction. The significance of this study comes from the fact that increased understanding of the preferences of CE formats will better serve library professionals' needs so they can continuously adapt to the ongoing evolution of public libraries as vital community centers of knowledge, information and services.

9. References

Abron, D. (2018). Journey to a makerspace. Public Libraries, 57(4), 14-15.

Al Ansari, H., \& al Khadher, O. (2011). Developing a leadership competency model for library and information professionals in Kuwait. Libri: International Journal of Libraries and Information Services, 61, 239-246. doi:10.1515/libr.2011.020

American Library Association. (2008). Core competencies. Retrieved from http://www.ala.org/educationcareers/careers/corecomp/corecompetences

American Library Association. (2012). Library competencies. Retrieved from http://www.ala.org/tools/atoz/library-competencies

American Library Association. (2014). Libraries of the future. Retrieved from http://www.ala.org/tools/future/trends American Library Association. (2018). State of America's libraries report 2018. Retrieved from http://www.ala.org/news/state-americas-libraries-report-2018/public-libraries 
American Library Association. (2019). State of America's libraries report 2019. Retrieved from http://www.ala.org/news/state-americas-libraries-report-2019

Association for Library Service to Children. (2015). Competencies for librarians serving children in public libraries. Retrieved from http://www.ala.org/alsc/edcareeers/alsccorecomps

Australian Library and Information Association (ALIA). (2014). The library and information sector: Core knowledge, skills and attributes. Retrieved from https://www.alia.org.au/about-alia/policies-standards-and-guidelines/library-and$\underline{\text { information-sector-core-knowledge-skills-and-attributes }}$

Babbie, E. R. (2015). The practice of social research (14th ed.). Belmont, CA: Wadsworth, Cengage Learning.

Bolan, K. (2016). The need for teen spaces in public libraries. Retrieved from Young Adult Library Services Association website: http://www.ala.org/valsa/guidelines/whitepapers/teenspaces

Bronstein, J. (2015). An exploration of the library and information science professional skills and personal competencies: An Israeli perspective. Journal of Librarianship and Information Science Research, 37, 130-138. http://dx.doi.org/10.1016/i.lisr.2015.02.003

Burns, E. A., Howard, J. K., \& Kimmel, S. C. (2016). Development of communities of practice in school library education. Journal of Education for Library and Information Science, 57(2), 101-111. doi:10.12783/issn.2328-2967/57/2/3

Christou, C., (2019). ALA and Google get libraries ready to code. Information Today, 36(4), 1819. 
Chartered Institute of Library and Information Professionals (CILIP). (n.d.). The professional knowledge and skills base. Retrieved from https://www.cilip.org.uk/page/pksb

Damron, M. (2019). A sensory wonderland: A programming space for the special needs community. American Libraries, 50(6), 24-25.

Hamden, R. K. A. (2017). The effect of (think - pair - share) strategy on the achievement of third grade student in sciences in the educational district of Irbid. Journal of Education and Practice, 8(9), 88-95.

Hamid, A., \& Soroya, S. (2015). Current trends of continuing education programs in LIS profession. Pakistan Library and Information Science Journal, 46(3), 4-12.

Harhai, M., \& Krueger, J. (2016). Competency-based professional development. Journal of Library Administration, 56(8), 939-956, doi: 10.1080/01930826.2016.1179478

Harrison, R. (2010). Unique benefits of conference attendance as a method of professional development for LIS professionals. The Serials Librarian, 59, 263-270. doi: $10.1080 / 0361526 X .2010 .489353$

Heinrichs, J. H., \& Lim, J. (2009). Emerging requirements of computer related competencies for librarians. Library and Information Science Research, 31(2), 101-106. doi:10.1016/j.lisr.2008.11.001

IFLA Library Services to Children and Young Adults Section, \& Rankin, C. (Ed.). (2018). IFLA guidelines for library services to children aged 0-18. Retrieved from International Federation of Library Associations and Institutions website: https://www.ifla.org/publications/node/67343

Johns, L. (2019). Yoga and mindfulness in libraries - and for library staff. Alki, 35(1), 10-14. 
Jordebrek, J. (2019). A podcast that delivers: Stork storytime talks shares early-literacy tips with expecting caregivers. American Libraries, 50(5), 18-19.

Khan, A., \& Rafiq, M. (2013). "Designing effective in-service training for librarians in Pakistan" (2013). Library Philosophy and Practice (e-journal). Retrieved from http://digitalcommons.unl.edu/libphilprac/1056

Library Leadership \& Management Association (LLAMA). (2016). Leadership and management competencies. http://www.ala.org/llama/leadership-and-management-competencies Document ID: 1c1ef45d-de79-a9f4-5565-33fd59b705ad

MacPherson, K. (2019). Courting libraries: Partnerships bring social services and restorative justice to communities. American Libraries, 50(6), 16-17.

Marcotte, A. (2019). Everyone on the same page: Adults with disabilities find engagement, community in book clubs. American Libraries, 50(6), 18-19.

Marken, J. A., \& Dickinson, G. K. (2013). Perceptions of community of practice development in online graduate education. Journal of Education for Library and Information Science, 54(4), 299-306.

McCafferty, A. S., \& Beaudry, J. (2017). The gallery walk: Educators step up to build assessment literacy. The Learning Professional, 38(6), 48-53.

Nonthacumjane, P. (2012). Key skills and competencies of a new generation of LIS professionals. IFLA Journal. Retrieved from https://doiorg.uri.idm.oclc.org/10.1177/0340035211430475

OCLC/IMLS. (2013). Coordinating continuing education for libraries and cultural institutions. Report from CE Summit. Coalition to Advance Learning. Retrieved from 
http://www.coalitiontoadvancelearning.org/wp-content/uploads/2015/10/CE-Summitreport.pdf

Ohio Library Council. (2014). Core competencies. Retrieved from http://olc.org/resources/education/core-competencies/

Oguz, F., Chu, C. M., \& Chow, A. S. (2015). Studying online: Student motivations and experiences in ALA-accredited LIS programs. Journal of Education for Library \& Information Science, 56(3), 213-231. doi:10.12783/issn.2328-2967/56/3/4

Partridge, H., Lee, J., \& Munro, C. (2010). Becoming "librarian 2.0": The skills, knowledge, and attributes required by library and information science professionals in a web 2.0 world (and beyond). Library Trends, 59(1), 315-335.

Patton, M. Q. (2002). Two decades of developments in qualitative inquiry: A personal, experiential perspective. Qualitative Social Work, 1(3), 261-283.

Peet, L., (2019). Mental wellness. Library Journal, 144(5), 48-53.

Peng, Y. (2019). A competency model of children's librarians in public libraries. Library Quarterly: Information, Community, Policy, 89(2), 99-115. doi:10.1086/702194

Popoola, B. O. (2019). Involving libraries in improving health literacy to achieve Sustainable Development Goal-3 in developing economies: A literature review. Health Information and Libraries Journal, 36(2), 111-120.

Rafiq, M., Jabeen, M., \& Arif, M. (2017). Continuing education (CE) of LIS professionals: Need analysis and role of LIS schools. The Journal of Academic Librarianship, 43(1), 25-33. doi:10.1016/j.acalib.2016.10.004 
Reference and User Services Association (RUSA). (2017). Professional competencies for reference and user services librarians. Retrieved from http://www.ala.org/rusa/resources/guidelines/professional

Sampsel, A. (2013). Finding the effects of think-pair-share on student confidence and participation. Honors Projects, 28. Retrieved from https://scholarworks.bgsu.edu/honorsprojects/28

Saunders, L., \& Jordan, M. (2013). Significantly different?: Reference services competencies in public and academic libraries. Reference \& User Services Quarterly, 52(3), 216-223.

State Library of North Carolina. (2015). Technology competencies. Retrieved from http://statelibrary.ncdcr.libguides.com/tech_competencies2016

Stephens, M. (2013). MOOCs for LIS professional development: Exploring new transformative learning environments and roles. Internet Learning, 2(2), 1-18.

Thompson, J. (2015). Changing needs, changing roles: How public libraries are expanding traditional service models to best serve their communities. Reference and User Services, Quarterly, 54(3), 2-5.

Tyagi, U., Yanthan, Z, Kumar, V., \& Tyagi, A. K. (2018). ICT competency framework of LIS professionals in India: A modular quotient. Annals of Library and Information Studies, 65(3), 170-176. Retrieved from http://nopr.niscair.res.in/handle/123456789/45392

Ullah, A., \& Ameen, K. (2018). Account of methodologies and methods applied in LIS research: A systematic review. Library and Information Science Research, 40(1), 53-60. https://doi.org/10.1016/j.lisr.2018.03.002 
Vega R. D., \& Connell, R. S. (2007). Librarians' attitudes toward conferences: A study. College \& Research Libraries, 68(6), 503-515.

Young Adult Library Services Association (YALSA). (2017). Teen services competencies for library staff. Retrieved from http://www.ala.org/yalsa/sites/ala.org.yalsa/files/content/YALSA TeenCompetencies $\underline{\text { web Final.pdf }}$

Tables

Table 1

Total Number of Post-its and Votes per Library Position

\begin{tabular}{lcc}
\hline Library Position & Post-its & Votes \\
\hline Library director & 79 & 217 \\
Adult services/reference librarian & 55 & 194 \\
Library staff & 62 & 179 \\
Children's/YA librarian & 78 & 209 \\
\hline Total & 274 & 799 \\
\hline
\end{tabular}

Table 2

Competencies for Library Director 


\begin{tabular}{|c|c|c|}
\hline Category & Sub-category & "Votes" \\
\hline \multirow[t]{4}{*}{$\begin{array}{l}\text { Library } \\
\text { Management } \\
(\mathrm{n}=121)\end{array}$} & $\begin{array}{l}\text { Library operations (including cataloging, collection development, } \\
\text { facilities management, policies, tech equipment, } \\
\text { management/troubleshooting, volunteer management, willing to } \\
\text { do any job staff does) }\end{array}$ & 45 \\
\hline & $\begin{array}{l}\text { Financial know-how (including budget/financial management, } \\
\text { fundraising and grant writing, municipal budgeting - library as } \\
\text { part of whole, using data for funding and explaining library to } \\
\text { town patrons) }\end{array}$ & 31 \\
\hline & $\begin{array}{l}\text { Strategic planning (including } 1 \text { yr plan } 5 \text { yr plan } 10 \text { yr plan, } \\
\text { developing library building program, outcome measurement, } \\
\text { project management skills, management skills/leadership) }\end{array}$ & 25 \\
\hline & $\begin{array}{l}\text { Staff relations (including ability to gather insights from people } \\
\text { within the organization, change management, human resources, } \\
\text { setting culture and norms, staff management and training) }\end{array}$ & 20 \\
\hline \multirow[t]{4}{*}{$\begin{array}{l}\text { Interpersonal } \\
\text { Skills }(n=100)\end{array}$} & $\begin{array}{l}\text { General communication skills (including clear communication } \\
\text { skills and open ear for staff and community, communication } \\
\text { skills, dealing with difficult people, diversity training, giving } \\
\text { feedback positive and negative when needed, good listener, } \\
\text { people skills, support ideas) }\end{array}$ & 45 \\
\hline & $\begin{array}{l}\text { Communication skills - public (including navigating political } \\
\text { waters, political acumen, political savvy and patience of a saint, } \\
\text { customer service) }\end{array}$ & 18 \\
\hline & $\begin{array}{l}\text { Communication skills - staff (including leadership and quality } \\
\text { feedback for staff, mentoring skills, negotiating change with staff, } \\
\text { ways to motivate staff) }\end{array}$ & 17 \\
\hline & $\begin{array}{l}\text { Staff relations (including ability to gather insights from people } \\
\text { within the organization, change management, human resources, } \\
\text { setting culture and norms, staff management and training) }\end{array}$ & 20 \\
\hline $\begin{array}{l}\text { Community } \\
\text { Involvement } \\
(\mathrm{n}=45)\end{array}$ & $\begin{array}{l}\text { Community engagement (including ability to find and meet the } \\
\text { needs of community, community involvement/engagement, } \\
\text { community outreach - to those outside usual patrons, how to } \\
\text { build community) }\end{array}$ & 32 \\
\hline
\end{tabular}


Library advocacy (including advocacy ability, advocacy working effectively w/ select board/board of trustees, familiarity with library services and ability to educate public)

Personal Traits Leadership traits (including critical thinking, self-control, smart, vision)

Positive perspective (including curiosity, innovative, passion, up to date and willing to try out innovative trends in the field)

Socio-emotional skills (including emotional intelligence, empathy, 9 social personality - ability to persuade)

Table 3

Competencies for Adult Services/Reference Librarian

\begin{tabular}{llc}
\hline Category & Sub-category & "Votes" \\
\hline Interpersonal & $\begin{array}{l}\text { People skills (including basic communication and ability to make } \\
\text { many different kinds of people comfortable, diversity training, } \\
\text { diversity/inclusion training, managing relationships with other } \\
\text { staff and with patrons (difficult patrons), managing relationships } \\
\text { with volunteer and volunteer group, mental illness } \\
\text { understanding, people skills) }\end{array}$ & \\
& $\begin{array}{l}\text { Customer experience (including able to listen to what patron(s) } \\
\text { really wants not what you think they want, communicate } \\
\text { confidence to helpless (technological) patron/customer, good } \\
\text { communication skills/ref interview, knowledge of customer } \\
\text { experience) }\end{array}$ & 31 \\
& $\begin{array}{l}\text { Presentation/professional communication (including ability to } \\
\text { challenge status quo, negotiating skills, public speaking, } \\
\text { teaching/presentation skills) }\end{array}$ & 13
\end{tabular}


Core Library Services $(n=68)$
Knowledge of and competency with library resources and

Services (including available services for adults i.e. talking books, comfort with analysis of print and electronic media (databases, websites), cross reference, genealogy skills, library services offered, reference resource knowledge, reliable online resources)

Readers advisory (including genre \& audience awareness, 25 Overdrive/ebook/edownloads knowledge, RA skills, read fiction, readers advisory (or how to use Novelist), ways to encourage literacy of all kinds)

Program/event planning (including adult programming, event planning, program/event planning skills

Tech Computer/technology knowledge and skills (including computer Competencies $(n=50)$

Community Connections $(n=33)$ and database training, computer skills, emergency computer training (using devices), how to print out picture and documents from a cell phone - wireless printing, library/tech trends, privacy and protection online, strong computer/tech literacy, troubleshooting tech)

Social media (including knowledge about social media, social media interest) community, understanding needs in community, social services local knowledge)

Community engagement (including community engagement outreach ideas, how to engage and involve with community, design thinking, community connections (i.e. services)

Personal Traits Approachable (including calm, friendly, nice and helpful, patience)

Outgoing (including curiosity to learn every day, curious, willing 10 to go the extra mile) 
Table 4

Competencies for Children's/YA Librarian

\begin{tabular}{|c|c|c|}
\hline Category & Sub-category & "Votes" \\
\hline \multirow[t]{3}{*}{$\begin{array}{l}\text { Personal Traits } \\
(\mathrm{n}=84)\end{array}$} & $\begin{array}{l}\text { Creative and flexible (including creativity, curiosity play } \\
\text { courage, enthusiasm and creativity, growth mindset, } \\
\text { innovative, sense of humor, sense of humor/flexibility, to be } \\
\text { around noise is good, performance skills) }\end{array}$ & 37 \\
\hline & $\begin{array}{l}\text { Socio-emotional understanding (including empathy, must love } \\
\text { working with kids and/or teens of all backgrounds and } \\
\text { temperaments, patience) }\end{array}$ & 25 \\
\hline & $\begin{array}{l}\text { Approachable (including approachable, calm, chill, relaxed } \\
\text { manner to make them feel comfortable approaching staff) }\end{array}$ & 22 \\
\hline \multirow[t]{3}{*}{$\begin{array}{l}\text { Knowledge of } \\
\text { Patrons and } \\
\text { Community } \\
(n=76)\end{array}$} & $\begin{array}{l}\text { Children/teen development (including brain development, child } \\
\text { and teen development, emotional intelligence, knowledge of } \\
\text { developmentally appropriate skills for all ages, mental health } \\
\text { training, teen emotional knowledge, understanding different } \\
\text { learning styles, be knowledgeable of gender identification and } \\
\text { an ally to all youth, challenges kids face tech social } \\
\text { understanding) }\end{array}$ & 35 \\
\hline & $\begin{array}{l}\text { Children/teen interests (including a strong understanding of age } \\
\text { group's interests, adaptability, ability to match kids with book } \\
\text { at their reading level/interest, finding their interests and } \\
\text { providing them with ways to pursue them, how to engage kids } \\
\text { with technology, knowledge of trends, knows trends good and } \\
\text { bad, diversity training) }\end{array}$ & 23 \\
\hline & $\begin{array}{l}\text { Outreach/community partnerships (including community } \\
\text { engagement/schools, community outreach connection with } \\
\text { schools and youth organizations, knowledge of needs in } \\
\text { location, outreach, partnerships with local schools etc.) }\end{array}$ & 18 \\
\hline
\end{tabular}


Core Library Services $(n=58)$

Interpersonal Skills $(n=38)$
Literacy development and support (including early literacy and how to support it, early literacy/juvenile/YA - adult readers, information literacy, knowledge of early literacy activities and approaches, literacy acquisition development, literacy child development awareness, literacy teaching reading expertise, needs to read kids fiction books, picture book knowledge)

General library operations (including know how to design 15 teen/kid space, knowledge of available resources, resources for collection development/weeding, staff/volunteer management)

Programming (including craft skills, makerspace, more ways to bring youth and teens into library)

Communication skills (including communication skills, crowd/parent control, how to talk to parents, work with other staff heads)

Child/teen relationship building skills (including ability to friend and educator, be a role model, behavior management skills, kid/teen specific people skills, rapport building)

Table 5

Competencies for Library Staff

\begin{tabular}{|c|c|c|}
\hline Category & Sub-category & "Votes" \\
\hline $\begin{array}{l}\text { Core Library } \\
\text { Services }(n=78)\end{array}$ & $\begin{array}{l}\text { Library resources, systems, and services (including familiarity with } \\
\text { books/collection, familiarity with library resources - physical and } \\
\text { digital, know the online resources in your library, reader's } \\
\text { advisory, ILL more CLOVER training, solid knowledge of ILS) }\end{array}$ & 38 \\
\hline
\end{tabular}


Cross-trained in all departments (including ability to alphabetize/organize using local system, cataloging, collection weeding, cross-training, general understanding of library and its mission and staff expertise, not just of one department, information literacy, knowledge of policies)

Program development and promotion (including ability to market and advertise for your library, program development, promoting programs, lead classes)

Interpersonal Skills $(n=73)$

Personal Traits $(n=44)$

Tech Competencies $(n=33)$
Customer experience (including customer service/experience, customer service saying yes!!, diversity training, coping with difficult patron interactions, during and after, interest in ensuring patron experience is positive and helpful, top notch communication and enthusiasm for libraries)

Collaborative working style (including collaborative learning/team building skills, communication problem solving within org, with staff, managing volunteers day to day with direction from director, negotiation and self advocacy, works well with other staff, permission to own their job/permission to develop their passion)

Openness (including curiosity, flexible, open to new ideas and change, understand that libraries have energy that's not always quiet)

Understanding of humanity (including consistency/fairness, empathy, patience, tolerance)

Friendly and helpful (including flexibility and kindness even under 10 pressure customer service, friendly, helpful (proactive), mission to serve others in the community - personal mission/passion, smile)

Troubleshooting skills (including ability to assist with technology, tech capable/troubleshooting, troubleshooting tech skills)

Basic technology skills (including computer skills/competencies, internet navigation, social media skills) 
Other $(n=7) \quad$ Health/mental health (including health, wellness, safety, how mental illnesses and neurological disorders manifest (basic), mental health first aid)

Table 6

Summary of CE Topics in Demand by Corresponding Roles

Topics in demand Role

Library Operations Director - administration in all departments, facilities management, policies, strategic planning, programming

Library Staff - crossed trained in departments, familiar with resources, RA services, programming

Financial Director

Management

Communication Director - with staff, patrons, and stakeholders (politically savvy)

Skills

Adult services/reference - people skills, good with diverse patrons, presentation skills

Community Director

Engagement

Customer Library staff, adult services/reference

Experience

Creative and Flexible Children's/YA librarian

Child/Teen Children's/YA librarian

Development 
Literacy Children's/YA librarian

Development

Computer Adult services/reference

Technology

Table 7

Total Pros and Cons by Format

\begin{tabular}{lcc}
\hline Workshop Format & Total Pros & Total Cons \\
\hline Combination face-to-face and virtual sessions & 16 & 13 \\
Face-to-face & 20 & 18 \\
Face-to-face university course & 17 & 31 \\
One shot workshop & 28 & 26 \\
Online university course & 26 & 31 \\
Post-graduate 12 credit certificate & 16 & 21 \\
Series of workshops over several weeks & 29 & 22 \\
Webinar & 24 & 31 \\
\hline
\end{tabular}

Figure captions

Figure 1: Example of one of the completed gallery walk stations

Figure 2: Example of one of the completed consensograms for preferred delivery formats

Figure 3. Total number of votes for delivery format of continuing education 
Figures

Figure 1

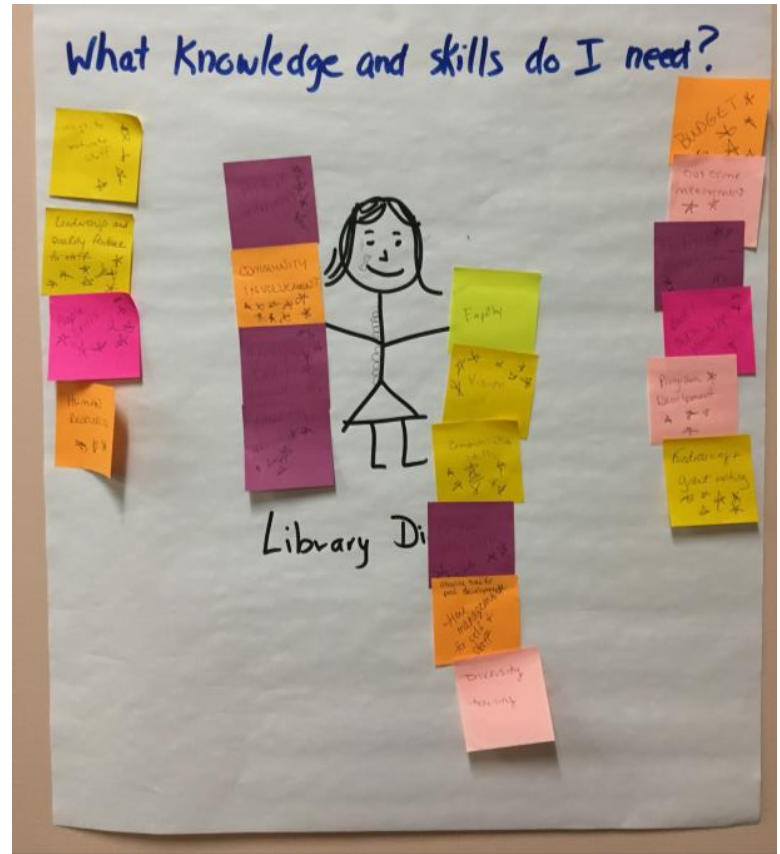

Figure 2

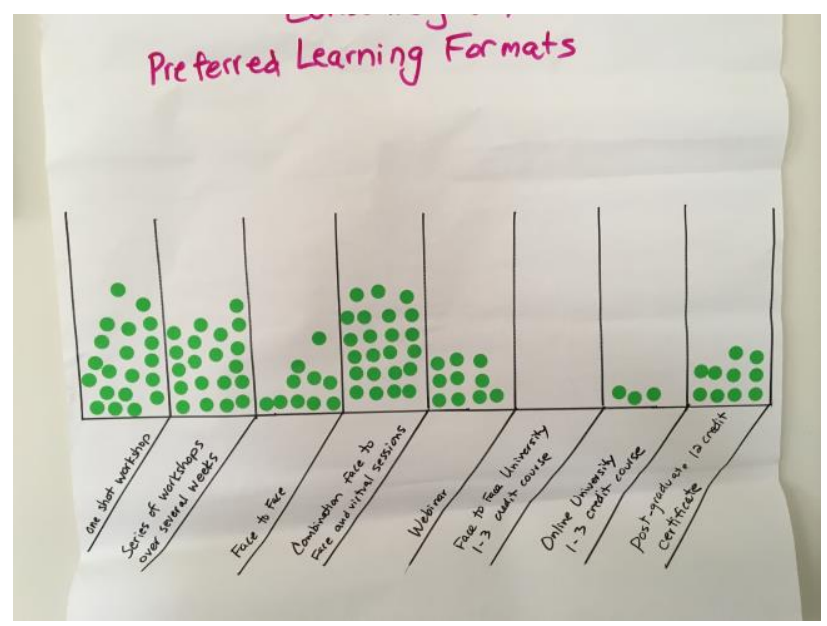


Figure 3

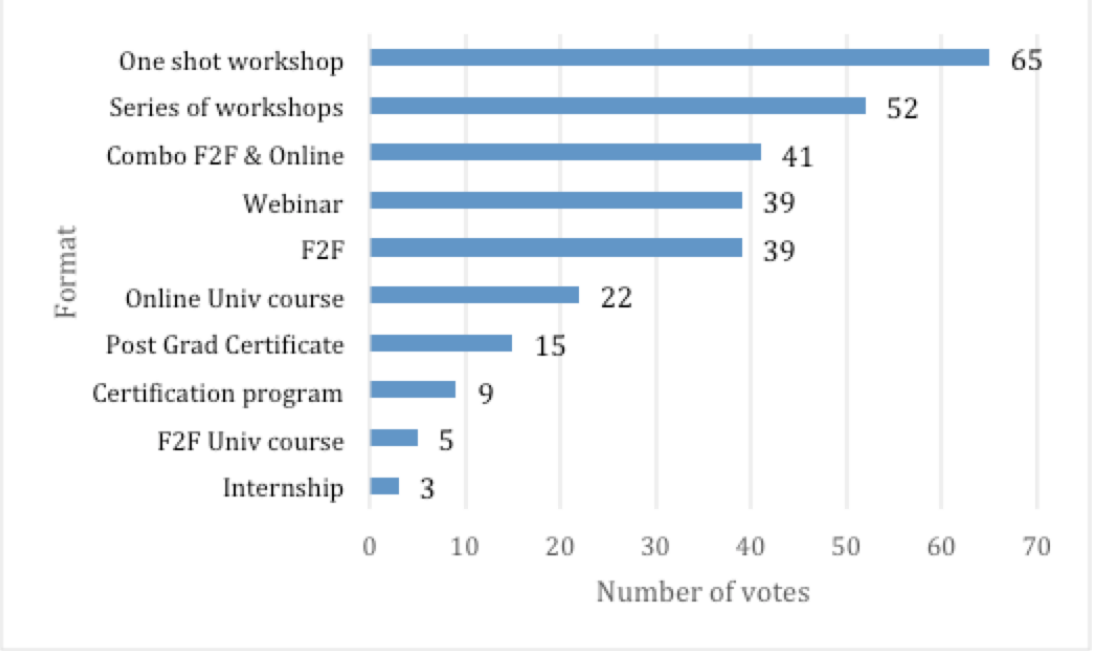

